\title{
Exploring How Emotional Intelligence Contributes to Virtual Teams: Interpretive Analysis of a Phenomenological Study
}

\author{
William L. Quisenberry, \\ Kaplan University, Fort Lauderdale, FL, USA
}

Doi: 10.19044/esj.2018.v14n5p19 URL:http://dx.doi.org/10.19044/esj.2018.v14n5p19

\begin{abstract}
The use of virtual teams continues to rise due to various factors such as increased pressure from competing forces, globalization, the need for improved efficiency, and technological advances. Despite the various benefits associated with high performing virtual teams, these specialized groups also experience extremely high failure rates. The increased failure can come as a result of various challenges including a lack of knowledge-sharing, limited communication, team members who lack self-managed and virtual teaming experience, and social loafing. While increased challenges are prevalent during virtual teaming arrangements, there seems to be evidence supporting that virtual team performance can be improved when team members have higher emotional quotients. This paper explores the potential benefits of emotionally intelligent virtual team members to understand how those with higher emotional quotients can potentially improve project success. The research involved analyzing a phenomenological study that interviewed 31 self-managed virtual team members via electronic questionnaires and surveys. This study follows up the original empirical research with an interpretative analytical review of the phenomenological findings pertaining to emotional intelligence and virtual teams. A thorough discussion regarding the findings and recommendations are provided.
\end{abstract}

Keywords: Virtual Teams, Dispersed Teams, Self-managed Teams, Emotional Intelligence

\section{Introduction}

As enterprises continue to expand operations into global markets with increased competition, the scope of projects has increased and the timelines to complete the work successfully have decreased. As such, organizations have been forced to bring the most knowledgeable employees together from different regions to complete projects collectively (Ginsburg, 2009; 
Quisenberry, 2011). To reduce expenditures, self-managed virtual teams work in dispersed self-managed climates and rely heavily on technology to communicate with team members and to manage and coordinate projects.

Managing teams has never been an easy task for leaders, and even more problems arise when leaders must manage virtual teams. Quisenberry (2011) provided research on self-managed virtual team members' common attributes and also provided significant data in regard to the leadership styles, strategies, and characteristics required to lead these teams, but the aim of this paper was to review Emotional Intelligence's impact on virtual team performance. Understanding whether Emotional Intelligence (EI) improves virtual team members' performance can help leaders understand if managers should intentionally seek these skill sets when staffing virtual teams.

Researchers indicated that virtual teams are challenged by unique problems that face-to-face teams do not encounter and also have increased exposure to risk (Horwitz, Bravington, \& Silvis, 2006; Kossler \& Prestridge, 2004; Malhotra, Majchrzak, \& Benson, 2007; Reed \& Knight, 2010). Virtual team members and leaders are required to take on unique tasks that face-toface teams typically do not have to, and trust, relationship building, project coordination, and collaboration are much more difficult in virtual project climates (Anantatmula \& Thomas, 2010; Bacon \& Blyton, 2006; Colquitt \& Piccolo, 2006; Cottrell, Neuberg, \& Li, 2007; Dani, Burns, Backhouse, \& Kochhar, 2006; Horwitz et al., 2006; Mancini, 2010; Panteli \& Tucker, 2010). Virtual teams are highly effective when operated correctly, but they fail more often than they succeed (Cramton, 2001; Furst, Reeves, Rosen, \& Blackburn, 2004; Gratton et al., 2007). Before teams can be properly constructed with team members and leaders, organizational leaders should understand what attributes and characteristics to look for while staffing projects.

Organizational leaders can be better prepared to construct managerial strategies for virtual projects by discovering if EI contributes to improved performance. Additionally, researchers and practitioners can seek to understand how EI can be leveraged and utilized to full potential, to increase team performance and accomplish organizational goals. This study was part of a broader research effort that sought to understand the common attributes and characteristics of self-managed virtual team members (Quisenberry, 2011). However, the content of this specific paper will focus on understanding if EI contributes to improved virtual team performance and if so, in what manner. A qualitative phenomenological research methodology was utilized in the original research project and 31 self-managed virtual team members from various industries participated in an electronic, email questionnaire. Follow-up email interviews were conducted to verify survey responses and to ask probing questions. 


\section{Rationale for methodological approach}

A qualitative, phenomenological, transcendental approach was utilized in the original study under review. The phenomenological method involves capturing the essence of human experience regarding a phenomenon from the perspective of participants (Moustakas, 1994). Phenomenologist focus on individuals who have had similar experiences or operate in similar environments and attempt to discover commonalities and shared meanings (Simon, 2006). This specific study involved seeking to understand if EI characteristics in self-managed team members contributed to improved project performance. These viewpoints came directly from the perspective of actual members of virtual teams. Due to limited time and resources, an ethnography, grounded theory, or case study design, which all would involve face-to-face interviews, data collection on site, or extended periods reviewing the actions of virtual team members, was not selected for the original study (Creswell, 2009). The researcher captured common threads and trends directly from virtual team members' viewpoints, and a qualitative, phenomenological approach was the best way to capture these perspectives (Simon, 2006). Because the study involved analyzing virtual team members, several participants were in different locations, and by utilizing surveys, the data were captured via electronic media communication, which is a method that virtual team members are accustomed to utilizing.

\section{Role of the researcher}

In the original research project dating back to 2011, the role of the researcher in the study was to collect, organize, and interpret the data and results. The researcher constructed and distributed the questionnaires utilized in the study and after receiving the results, the information was loaded into the NVivo software program to ensure the proper aspects of the problem were addressed (Creswell, 2009). After the software program produced the findings of the questionnaires, the data were analyzed for inductive, reoccurring trends and common threads to identify the themes that emerged from the results (Moustakas, 1994). The researcher provided an analytical review and description of the emotional intelligence data in a formal report, which appears later in this paper.

During the analytical review, the researcher clearly explained the characteristics and attributes commonly associated with self-managed virtual team members. The common results concerning the managerial style that virtual team members preferred were used while overseeing them as well as what leadership styles they found most effective will also be discussed. An analysis of the major differences that virtual team members recognized while comparing dispersed teams to collocated teams is discussed. Although previous literature provides insight into common attributes of self-managed 
virtual team members as well as the types of leadership styles that have succeeded or failed in the past, the current qualitative study involved gaining insight into the research problem from the participants' perspective (Moustakas, 1994). The instrument used to gain the phenomenological data was a survey with open-ended questions and the researcher. Using this method, the researcher obtained written descriptions of the participants' feelings, thoughts, and experiences (M. Simon, 2006). This form of data collection addressed the phenomenon and allowed the researcher to gather rich data from a large pool of participants. The researcher then followed up this previous research with an interpretative analysis of the phenomenological data, applying a new review and literature to the data. Since the researcher was the actual instrument, this offered additional opportunities to revisit the findings and draw updated conclusions, while continuing to extend the research seven years after the original study.

\section{Participants}

The participants of the research study were 31 individuals who are selfmanaged virtual team members. The participants were dispersed professionals from various industries and positions. The participants were either members of an international project management association or faculty, staff, and students from an online university. Including these participants allowed the researcher to sample individuals who work in dispersed self-managed climates, which can be extrapolated to the larger self-managed virtual team population. The years of experience working in self-managed virtual climates varied, but all participants were required to have at least one year of virtual team experience to participate in the study.

The researcher utilized an online university's research participant portal as well as professional newsletters and social media announcements from the project management association to gain access to the participants. All data concerning the participants and their specific organizations were classified and private. The only information included in the research document was the professional background of the participants, the particular industry they work within, virtual team experience, collocated team experience, and age. This information was included to provide greater analytical value and potential for commonalities and threads relating to industry and demographic.

Participants were informed of the data collection procedures prior to participating in the study. The participants provided consent to participate in the study prior to taking the qualitative survey, and by clicking on the link of the survey, they accepted the terms and agreed to participate. Although both organizations featured in the study helped the researcher locate potential participants and assisted with sending out the electronic link to the survey, the organizations did not know who responded to the survey. The responses from 
the electronic questionnaire were automatically sent back to the researcher in a secure Survey Monkey portal. The researcher was the only individual who had access to this encrypted, password-protected portal, which helped ensure the participants were protected.

The sample of participants was gathered using purposive techniques. In accordance with the nonrandom purposeful sampling strategies, the researcher also used a snowball method to accumulate additional participants. The researcher gathered a pool of potential candidates from announcements released by the project management association and the online university's research participant portal. The methods of communication the organizations utilized were Internet and e-mail, and the informed consent form was included on the Internet as well as in the introductory/announcement e-mail that described the background, purpose, procedures of the study, and link to the survey.

\section{Review of the literature}

\section{EI's Contributions to Virtual Team Leadership}

Having a high Emotional Quotient (EQ) is important for leadership, especially in team environments. Prati, Douglas, Ferris, Ammeter and Buckley (2003) described EI as the ability to understand others in a social context, understand emotional reactions, and use this knowledge to influence others through emotional control. Team leaders with high EQs can analyze others' emotions and control their own emotions when interacting with subordinates (Prati et al., 2003). Understanding one's own emotions and also having the ability to understand employees' emotions allow leaders to build appropriate relationships and lead effectively (Prati et al., 2003). Leaders with high EQs can strategize and motivate employees because they can predict the types of emotional reactions team members may have in certain situations and can thus plan accordingly. Employees who possess high EQs also have the ability to perform at higher levels in team environments, interact with team members more effectively, and contribute to innovative thinking and positive teamoriented atmospheres (Prati et al., 2003). High EQs offer a level of balance to leaders relying on charismatic leadership because the leadership style forces them to consider the thoughts and feelings of others instead of focusing on narcissistic mind-sets that contribute to negative atmospheres and reduce cohesion.

Cohesion is critical, because any team-based environment will involve collaboration to complete coordinated efforts. EI has positive effects on relationship management, which is important in any environment that involves collaboration (Prati et al., 2003). Self-awareness, self-motivation, empathy, and emotional management all play critical roles in team interaction and collaboration and are major aspects of EI. Emotionally intelligent leaders are 
self-motivated, have positive outlooks on life, and are more cheerful, which are characteristics that can transfer to the subordinate team members, thus improving the levels of motivation and the working atmosphere (Prati et al., 2003). EI personality types are the exact opposite of some of the selfabsorbing, negative aspects found in some charismatic leaders. The ability to adjust leadership styles depending on the specific employee will be easier for a manager who can gauge and predict emotional responses. These capabilities can play a significant role on influencing behavior and performance amongst virtual teams.

\section{EI's Contribution to Virtual Team Member's Performance}

High EQs go beyond good leadership and also could contribute to viable virtual team membership. When evaluating potential members of selfmanaged virtual teams, research showed that EI can be used as a key determinant depicting whether the prospect will fit within these teams (Frye, Bennett \& Caldwell, 2006). Frye et al. (2006) defined EI as the emotional and social aspects of intelligence. Empathy is highly regarded as a key attribute of informal leaders that emerges from self-managed groups and ultimately helps steer projects along (Ferbrache, 2009; Frye et al., 2006). Research also supports the idea that higher levels of EI from an individual and team perspective contribute to increased conflict resolution in self-managed team environments (Frye et al., 2006). EI has been linked to more collaborative thinking, whereas a lack of EI typically relates to domineering, forceful behavior, which is not a positive attribute in team-based environments. Not only are high EQ levels pertinent to leaders, but the benefits also transfer to the team members. When seeking to determine whether potential staff members will be a good fit on self-managed virtual teams, gauging the potential team members' level of EI can act as an assessment instrument. However, even with this information, EI still may not be a reoccurring common attribute found in actual team members; it has just been identified as a trait that can be beneficial.

The research studies that support the benefits of high EQ levels have been discussed within this review of the literature. Despite the positive benefits of emotionally intelligent team members, Rozell and Scroggins (2010) found that members with high EI levels operating in a self-managed atmosphere could reduce the level of group satisfaction. Rozell and Scroggins's research was limited because it sampled business students operating in a team atmosphere, instead of actual team members in a corporate setting. However, despite the reduction in validity found in the population, Rozell and Scroggins provided a potentially negative aspect of high EI team members, which could require further investigation with a different population. 
Additionally, although EI has been linked to transformational leaders, some of the attributes of EI seem to contradict those of highly charismatic, transformational leaders. EI has been linked to successful leaders at several large organizations. In addition to high levels of EI, these successful leaders were also known to have conflict resolution skills, the ability to agree, and the flexibility to adapt (Krosigk, 2007). Researchers have also found that not all great leaders are necessarily charismatic people persons, but instead some are reserved, quiet types who would rather stay to themselves (Krosigk, 2007). Not all leadership must be charismatic or transformational to be effective, but it depends on the environment, the organization, and ultimately the team that the leader is responsible for overseeing.

It is important to also consider the impact of trust and empathy in virtual teaming atmospheres. Virtual team members, as well as transformational leaders, have been credited with high levels of EI and a stronger ability to manage, respond to, and understand the emotions of fellow team members (Prati et al., 2006). Empathy contributes to greater relationship management because it forces leaders and team members to consider the group when acting. Removing selfishness will contribute to a more collective, cohesive atmosphere, but empathetic styles such as these could be much tougher to implement in dispersed atmospheres because personal feelings tend to be more removed in virtual climates. High EQs contribute to an ability to mentor and steer employees to ensure they develop into leaders and reach their full potential.

As such, it is potentially beneficial for organizational leaders to institute employee management programs that utilize mentoring to ensure the organization or team continues to develop and grow, which is becoming increasingly important as many baby boomers are continuing to leave the workforce for retirement (Hutcheson, 2006). Mentoring leadership styles correlate with charismatic, transformational leadership, which aims to develop talent into future management positions and allow them to grow, instead of focusing on short-term goals. Successful mentees typically possess the ability to work through issues and are continuous learners, are avid listeners, and accept feedback and advice well (Hutcheson, 2006). Some of the same attributes found in good mentees, such as humility, the ability to accept feedback, and the ability to work through tough issues, also exist in successful virtual team members who have high levels of EI. In essence, the roles of successful mentors and mentees show similarities to the same attributes of transformational leaders and self-managed virtual team members.

The contributions that EI can have on individuals have been discussed in this review; however, there is still a need to understand the impact that EI can have on the overall team. Rapisarda (2002) contended that the level of emotional competency in team members directly relates to the degree of team 
cohesion and performance. EI competencies of influence, empathy, and achievement orientation positively contributed to team cohesiveness and performance (Rapisarda, 2002). As a result, Rapisarda recommended that managers should attempt to recognize and construct teams made up of individuals with EI competencies of empathy and achievement orientation to construct successful, more cohesive teams. Again it seems that seeking team members with high levels of EI can be a strong predetermining factor and contribute to team success. Despite these findings, team leaders must be careful not to seek one type of personality trait because the level of inclusion and diversity can be hindered.

Despite the risk associated with staffing teams with one personality type, it is still apparent that several team benefits can result from EI. EI allows teams to work collectively, collaborate more with different types of colleagues, and also communicate effectively (Frye et al., 2006). High levels of EI are beneficial to leaders and individual team members, but a team that has high levels of EI is typically more effective, is more productive, and can successfully thrive in virtual climates. Managers who have high EQs can operate in intense climates, where they must manage change and inspire employees (Frye et al., 2006). Figure 1 was developed from Goleman's (1995) theory of EI and depicts how virtual team members can benefit from high EQs.

\begin{tabular}{|c|c|c|}
\hline & $\begin{array}{l}\text { Self } \\
\text { Personal Competence }\end{array}$ & $\begin{array}{l}\text { Other } \\
\text { Social competence }\end{array}$ \\
\hline Recognition & $\begin{array}{l}\text { Self-Awareness } \\
\text { - Emotional self-awareness } \\
\text { - Accurate self-assessment } \\
\text { - Self-confidence }\end{array}$ & $\begin{array}{l}\text { Social Awareness } \\
\text { - Empathy } \\
\text { - Service orientation } \\
\text { - Organizational } \\
\text { awareness }\end{array}$ \\
\hline Regulation & $\begin{array}{l}\text { Self-Management } \\
\text { - Self-control } \\
\text { - Trustworthiness } \\
\text { - Conscientiousness } \\
\text { - Adaptability } \\
\text { - Achievement drive } \\
\text { - Initiative }\end{array}$ & $\begin{array}{l}\text { Relationship Management } \\
\text { - Developing others } \\
\text { - Influence } \\
\text { - Communication } \\
\text { - Conflict management } \\
\text { - Leadership } \\
\text { - Change catalyst } \\
\text { - Building bonds } \\
\text { - Teamwork \& collaboration }\end{array}$ \\
\hline
\end{tabular}

Figure 1. Graphical representation of Daniel Goleman's framework of emotional competencies. From The Emotionally Intelligent Workplace (p. 2), by D. Goleman, Consortium for Research on Emotional Intelligence in Organizations, 2001. Copyright 2001 by Jossey-Bass. 
By having a high EQ, these individuals can recognize and regulate emotions, which allows them to be more aware, manage their own emotions, and manage relationships with team members. These factors are important in virtual, collaborative atmospheres.

\section{Results}

The purpose of the original study was to understand the common characteristics and attributes of self-managed virtual team members using the lived experiences and perspectives of actual virtual team participants. This specific paper focused on the contributions that EI has on self-managed virtual team performance. The study generated significant results that contributed to understanding the common characteristics of virtual team members that can both contribute to success and also hinder project progression and that information was analyzed by the researcher to understand the impact of EI on virtual project team performance. It is important to understand not only the positive characteristics of virtual team members, but also the negative characteristics that reduce the outcome and progress of virtual projects so leaders and organizations can obtain a better idea of the team members that should not participate on the groups. The researcher used the expressions and viewpoints of the participants to construct a virtual team personality matrix, presented in Table 1. The matrix was developed by taking the perceptions of the participants and relating them back to Goleman's (1995) EI graphical representation (see Figure 1). The table depicts how the underlying foundations of EI relate to virtual team personality traits, characteristics, and attributes.

Table 1

Virtual Team Personality Matrix

\begin{tabular}{ccccc}
\hline & \multicolumn{2}{c}{ Positive traits } & Social & Negative traits \\
\cline { 2 - 5 } & Personal competence & competence & Personal & competence \\
Recognition & Self-awareness: & Social awareness & Self-awareness & Social awareness \\
& Flexibility & Effective & Rigidity when & Selfishness \\
& Sector and segment & listening & not required & Silo mentality \\
knowledge/expertise & Interpersonal & Inflexibility & Lack of respect \\
Technology & skills & Lack of & for others \\
awareness & Understanding & awareness & Larticipation \\
Character & Multicultural & & \\
Trustworthiness & awareness & & \\
Integrity & Comprehension & & \\
& skills & & \\
& Helpful & &
\end{tabular}




\begin{tabular}{|c|c|c|c|c|}
\hline Regulation & $\begin{array}{c}\text { Initiative } \\
\text { Driven } \\
\text { Self-motivation } \\
\text { Independent } \\
\text { Personal } \\
\text { responsibility } \\
\text { Accountability } \\
\text { Self-managed } \\
\text { Thoughtful } \\
\text { preparation } \\
\text { Intuitive } \\
\text { Punctuality } \\
\text { Timelines } \\
\text { Professionalism } \\
\text { Focused } \\
\text { Organized } \\
\text { Task oriented } \\
\text { Multitasking abilities } \\
\text { Self-discipline } \\
\text { Work ethic } \\
\text { Outgoing }\end{array}$ & $\begin{array}{c}\text { Relationship } \\
\text { management } \\
\text { Clear } \\
\text { communication } \\
\text { Direct } \\
\text { communication } \\
\text { Great } \\
\text { communication } \\
\text { Open } \\
\text { communication } \\
\text { People skills } \\
\text { Trust } \\
\text { Collaborative }\end{array}$ & $\begin{array}{l}\text { Dependent } \\
\text { Lack of } \\
\text { accountability } \\
\text { Laissez-faire } \\
\text { attitude } \\
\text { Lack of } \\
\text { professionalism } \\
\text { Procrastination } \\
\text { Lack of focus } \\
\text { Poor time- } \\
\text { management } \\
\text { skills } \\
\text { Lack of } \\
\text { discipline } \\
\text { Nonmotivated } \\
\text { Lazy } \\
\text { Lack of } \\
\text { organization } \\
\text { Lack of initiative } \\
\text { Lack of self- } \\
\text { motivation } \\
\text { Lack of focus }\end{array}$ & $\begin{array}{c}\text { Relationship } \\
\text { management } \\
\text { Long- } \\
\text { windedness } \\
\text { Lack of } \\
\text { communication } \\
\text { Unwilling to } \\
\text { contribute } \\
\text { Ineffective } \\
\text { communicator }\end{array}$ \\
\hline
\end{tabular}

The personal characteristics and attributes of virtual team members produced a significant number of invariant constituents and subcategories. The ability to be self-motivated, require limited oversight from management, enjoy and thrive in autonomous atmospheres, possess superior organizational skills, and have excellent collaboration and team-building skills were some of the invariant constituents/subcategories that continued to emerge from the results. Most participants noted being self-motivated; $38 \%(n=12)$ of the participants felt being self-motivated was a necessary characteristic for virtual team members to possess. As Participant 24 stated, "A virtual team member has to have a self-management attitude and mentality, like a change agent or problem solver."

Participants made it clear that virtual team employees also must possess excellent written and verbal communication skills to thrive in dispersed environments. This invariant constituent was expressed as a necessary characteristic by $18(58 \%)$ of the participants. Additionally three participants (9\%) specifically identified written communication skills as being more important than verbal communication while working in a virtual setting. Participant 26 discussed the importance of communication when she stated,

Communication is another factor, often team member in virtual teams may misunderstand the information that is being exchanged in emails or 
discussion boards. As terms used at times can mean something different depending on where you live. Not seeing the facial expression or hearing the person's tone when messages are sent could cause the individual to miss valuable cues, preventing them from asking the right questions.

Table 2 Identified Themes and Supporting Statements-Personal Characteristics Contributing to Success or Failure on Virtual Teams

\begin{tabular}{|c|c|c|}
\hline \multirow[b]{2}{*}{ Theme } & \multicolumn{2}{|c|}{ Participants' supporting statements } \\
\hline & Positive characteristics & Negative characteristics \\
\hline $\begin{array}{c}\text { Successful virtual } \\
\text { team members are } \\
\text { self-motivated, driven }\end{array}$ & $\begin{array}{c}\text { "A virtual team member has to have a } \\
\text { self-management attitude and } \\
\text { mentality, like a change agent or } \\
\text { problem solver" } \\
\text { "Team members must be inwardly } \\
\text { motivated to accomplish specific } \\
\text { tasks" }\end{array}$ & $\begin{array}{l}\text { "Not being able to solve } \\
\text { problems on your own" } \\
\text { "Looking to management to } \\
\text { resolve issues, not having the } \\
\text { ability to work through complex } \\
\text { problems or issues" } \\
\text { "In my experience, individuals } \\
\text { that have to have a process } \\
\text { written out for every single issue } \\
\text { or step they should take, make } \\
\text { horrible virtual team members, } \\
\text { especially in self-managed } \\
\text { climates. }\end{array}$ \\
\hline $\begin{array}{l}\text { Successful virtual } \\
\text { team members are } \\
\text { independent, } \\
\text { autonomous, problem- } \\
\text { solvers }\end{array}$ & $\begin{array}{c}\text { "Virtual team members must have a } \\
\text { degree of latitude to complete } \\
\text { objectives" } \\
\text { "Virtual team members must be able } \\
\text { to work independently" } \\
\text { "A successful virtual person is } \\
\text { motivated by that } \\
\text { freedom/empowerment. They will } \\
\text { more likely be more productive." } \\
\text { "They cannot have the personality } \\
\text { types that wait for } \\
\text { management/leaders to get involved } \\
\text { to resolve problems, but instead they } \\
\text { have to take the initiative to go out } \\
\text { find resolutions to problems } \\
\text { themselves" }\end{array}$ & \\
\hline $\begin{array}{l}\text { Successful virtual } \\
\text { team members must } \\
\text { have a sense of } \\
\text { personal } \\
\text { accountability, } \\
\text { responsibility }\end{array}$ & $\begin{array}{c}\text { "Sense of personal responsibility" } \\
\text { "Accountability" } \\
\text { "Personal accountability." }\end{array}$ & \\
\hline $\begin{array}{c}\text { Effective } \\
\text { communication is } \\
\text { important to virtual } \\
\text { teams }\end{array}$ & $\begin{array}{c}\text { "Ability to speak up and } \\
\text { communicate effectively" } \\
\text { "Listen effectively - allow for pauses } \\
\text { for others to speak" } \\
\text { "Communication (written and oral), } \\
\text { ability to be concise" } \\
\text { "Must be able to communicate } \\
\text { proactively." }\end{array}$ & $\begin{array}{c}\text { "People can't see body language, } \\
\text { so adequately explaining your } \\
\text { thoughts is key" } \\
\text { "Not communicating big } \\
\text { challenges" } \\
\text { "Lack of communication" } \\
\text { "Not listening or being unwilling } \\
\text { to contribute potentially vital } \\
\text { information." }\end{array}$ \\
\hline
\end{tabular}




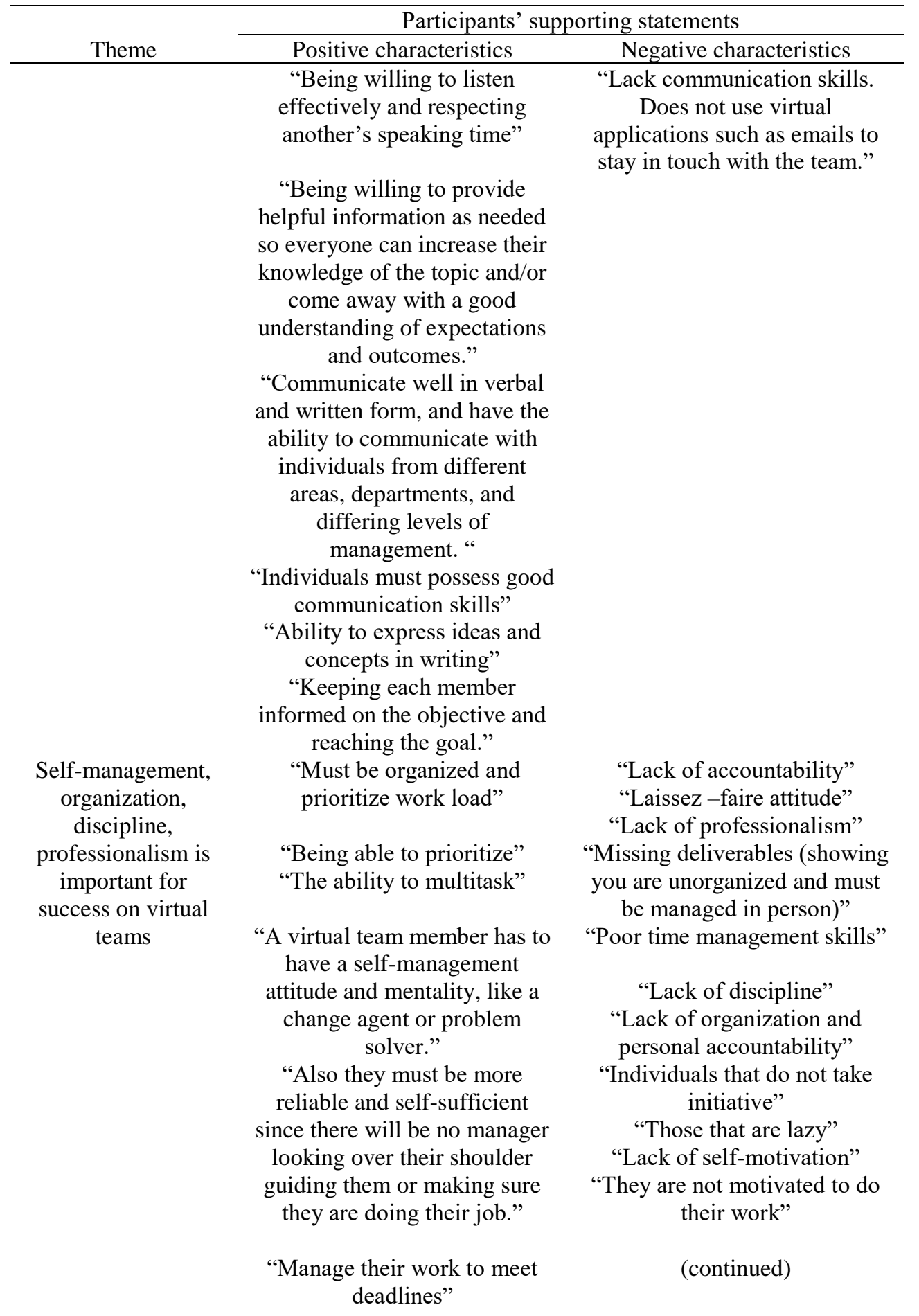




\begin{tabular}{|c|c|c|}
\hline \multirow[b]{2}{*}{ Theme } & \multicolumn{2}{|c|}{ Participants supporting statements } \\
\hline & Positive characteristics & Negative characteristics \\
\hline $\begin{array}{l}\text { Successful virtual } \\
\text { team members } \\
\text { must have good } \\
\text { interpersonal } \\
\text { skills such as } \\
\text { tolerance, ability } \\
\text { to work with all } \\
\text { types of people }\end{array}$ & $\begin{array}{l}\text { "Not taking things personally" } \\
\text { "Virtual team members must } \\
\text { possess people skills" } \\
\text { "Multi-cultural awareness" } \\
\text { "Personal styles and learning } \\
\text { styles appreciation" } \\
\text { "They also have to work well } \\
\text { with different cultures" } \\
\text { "Comprehension of others } \\
\text { communication/writing style" } \\
\text { "Intuitiveness of others } \\
\text { statements" }\end{array}$ & \\
\hline \multirow{5}{*}{$\begin{array}{l}\text { Virtual team } \\
\text { members must be } \\
\text { team players, } \\
\text { collaborative }\end{array}$} & "Willingness to help" & $\begin{array}{c}\text { "Lack of respect for } \\
\text { teammates" }\end{array}$ \\
\hline & "Have to be a team player" & $\begin{array}{l}\text { "Not being focused on the } \\
\text { contributions of others" }\end{array}$ \\
\hline & "Collaboration" & $\begin{array}{l}\text { "Lack of attendance or } \\
\text { participation. Easy to not attend }\end{array}$ \\
\hline & "Team bonding" & $\begin{array}{c}\text { a virtual team meeting as } \\
\text { oppose to a face-to-face team } \\
\text { meeting often due to competing } \\
\text { priorities or due to lack of } \\
\text { interest." } \\
\text { "Someone who is not a team } \\
\text { player" } \\
\text { "They do not care that the team } \\
\text { missed deadlines. Does not } \\
\text { work with the team" }\end{array}$ \\
\hline & & $\begin{array}{c}\text { "Lack of awareness of } \\
\text { strengths/weaknesses of team } \\
\text { members" }\end{array}$ \\
\hline \multirow{3}{*}{$\begin{array}{c}\text { Virtual team } \\
\text { members must } \\
\text { have experience, } \\
\text { skills, expertise }\end{array}$} & $\begin{array}{l}\text { "Sector and segment } \\
\text { knowledge" }\end{array}$ & $\begin{array}{c}\text { "Lack of knowledge about your } \\
\text { area of expertise" }\end{array}$ \\
\hline & "Technology awareness" & $\begin{array}{l}\text { "Another negative factor, } \\
\text { surprisingly, is slow typing" }\end{array}$ \\
\hline & $\begin{array}{l}\text { "Fluent use of technology is the } \\
\text { second attribute." }\end{array}$ & \\
\hline
\end{tabular}


Table 3

Thematic Categories and Invariant Constituents-Personal Characteristics Contributing to Success or Failure on Virtual Teams

\begin{tabular}{|c|c|c|}
\hline \multirow[b]{2}{*}{ Invariant constituents } & \multicolumn{2}{|c|}{$\begin{array}{l}\text { Participants to offer this } \\
\text { experience }\end{array}$} \\
\hline & No. & $\%$ \\
\hline Virtual team members must be effective communicators/listeners & 18 & 58 \\
\hline $\begin{array}{l}\text { Virtual team members must be responsible, self-managed, have } \\
\text { personal accountability, strong work ethic }\end{array}$ & 12 & 38 \\
\hline $\begin{array}{l}\text { Virtual team members must be team players, collaborators, } \\
\text { participate, not be selfish }\end{array}$ & 7 & 22 \\
\hline Virtual team members must be self-motivated, driven, independent & 6 & 19 \\
\hline $\begin{array}{c}\text { Virtual team members must have good written communication } \\
\text { skills }\end{array}$ & 3 & 9 \\
\hline $\begin{array}{c}\text { Virtual team members must have good interpersonal skills, be } \\
\text { outgoing }\end{array}$ & 3 & 9 \\
\hline Virtual team members must be flexible & 2 & 6 \\
\hline $\begin{array}{l}\text { Virtual team members must be tolerant, understanding of others' } \\
\text { personalities, cultures }\end{array}$ & 2 & 6 \\
\hline Virtual team members must have integrity, character & 2 & 6 \\
\hline $\begin{array}{l}\text { Virtual team members must be technologically skilled, have } \\
\text { expertise in their field }\end{array}$ & 2 & 6 \\
\hline $\begin{array}{l}\text { Virtual team members must understand their role/purpose as part } \\
\text { of the virtual team }\end{array}$ & 2 & $\begin{array}{l}6 \\
6\end{array}$ \\
\hline Virtual team members must be sensitive to time zones & & \\
\hline Virtual team members must have a sense of humor & 1 & 3 \\
\hline Virtual team members must have respect & 1 & 3 \\
\hline Virtual team members must be confident, low stress & 1 & 3 \\
\hline Virtual team members must be self-aware & 1 & 3 \\
\hline Virtual team members must not take things personally & 1 & 3 \\
\hline Virtual team members must be able to multitask & 1 & 3 \\
\hline $\begin{array}{l}\text { Virtual team members must understand other's contributions, } \\
\text { strengths and weaknesses }\end{array}$ & 1 & 3 \\
\hline
\end{tabular}

\section{Discussion}

The first question sought to understand the common characteristics and attributes of virtual team members and to determine the type of employees that leaders and organizations should seek while staffing these teams. The analysis of the results showed that individuals who were self-motivated and required limited oversight from management were typically a part of the groups. Possessing self-management capabilities is a major component of Goleman's (1995) EI theory. The results were also very similar to Ginsburg's (2009) findings that revealed self-managed employees who were self-motivated, innovative, and trustworthy made good virtual team members. Being able to operate in dispersed environments successfully with limited oversight from management is a major competitive advantage of virtual teams and one of the primary reasons many organizations have decided to implement the groups (Amurgis, 2007; Copeland, 2006; Qureshi et al., 2006; Thomas \& Bostrom, 2010). As this benefit is such an important aspect to virtual groups, it makes sense that the ability to remain self-motivated and the ability to execute 
strategies successfully with limited oversight were positive attributes of these teams.

Being very organized and outgoing and possessing the ability to remain focused for extended periods of time were the common traits of virtual team members. These traits were somewhat related to the findings that Ginsburg (2009) discovered but were not directly mentioned by the participants of that study. Two other attributes that emerged were team members' ability to work though complex problems with limited oversight from management and also having an extremely intuitive attitude. Virtual team members should have the ability to think creatively and have high levels of initiative to go out and find answers without managers guiding them to resolutions.

Although virtual team members must have the ability to take initiative and solve problems without help from management, another characteristic identified was the need for virtual team members to be highly collaborative and work with other team members. Collaboration was one of the major components discussed by previous researchers and was apparent within the review of the literature in the current study (Bielski, 2005; Brown \& Moshavi, 2005; Ginsburg, 2009; Wagner \& Harter, 2007). Participant 24 also supported these thoughts:

In a virtual setting, with limited oversight from leaders, employees and team members have to possess the ability to think through issues and work collectively with team members to find resolutions to those issues. Sometimes this will involve thinking outside of the box, not following standard processes or operating procedures or learning how to do something new. There is not always going to be a pretty nice and neat process checklist available for the team members to follow, they have to develop the ability to just get things done, find the answer, and talk to the decision-makers, whatever it takes to get the job done. These individuals make great virtual team members, those that lack these abilities and want someone to constantly hold their hand are the absolute worst and it is extremely frustrating to work with these types of team members, because the more intuitive team members typically ends up having to carry their load and do extra work for the sake of the project.

Virtual team members also were seen as having a sense of accountability and responsibility in regard to the project. This characteristic meant that they were willing to be held accountable for their decisions as individuals and as a collective group. This is important because virtual teams often receive more empowerment and decision-making leeway and thus must be able to take responsibility for their decisions despite the outcome. Individuals who do not take responsibility or like to blame others for the 
outcome and results of projects would not fit well in self-managed virtual atmospheres.

Accountability was not a character trait discussed in great detail by previous virtual team researchers and thus this finding in regard to the importance of this trait provided more insight into this phenomenon. Malhotra et al. (2007) partially discussed responsibility, as it was identified as a trait that would reduce social loafing. Finding team members who are willing to take accountability and be held responsible for their actions and decisions could improve the performance of the group.

Several participants identified communication abilities and methods continuously throughout the course of the data collection. Virtual team members were identified as possessing superior communication capabilities. These capabilities included not only having the ability to communicate effectively and in a clear manner, both written and verbally, but also being excellent listeners and message decoders. A sufficient amount of previous research discussed virtual team employees' abilities to communicate and their need to understand and leverage technology to communicate more effectively.

The art of listening was not discussed in great detail within the literature. However, an interesting aspect of listening is it is one of the primary traits associated with individuals who have high emotional quotients (Hutcheson, 2006). Again, this discovery supports the theory that individuals with higher levels of EI make better virtual team members and virtual team leaders. Listening and having the ability to decode messages properly allows virtual team members to understand information flowing through technological media, which would mean that they do not have the luxury of picking up on nonverbal cues or hearing tone inflections.

Due to limited social interaction, virtual team members were also seen as having an introverted personality style. However, virtual team members were not seen as being overly introverted, because they still need to have the ability to reach out to others for help and clarification and also were identified as possessing great interpersonal skills. This is similar to Ginsburg's (2009) findings that virtual team members should not be overly extroverted or demanding and likewise they likely should not be overly introverted. The findings within the study indicated that although there is less social interaction, virtual team members have the ability to collaborate well with different cultures and groups of people to ensure that the project is executed effectively. These traits again aligned with those discussed by Goleman (1995) and are characteristics of individuals with high emotional quotients.

Virtual team members also possessed trustworthiness and integrity. These individuals were seen as having the ability to obtain the trust of fellow team members more quickly, which was identified in previous research literature as an extremely important aspect in virtual environments (Bacon \& 
Blyton, 2006; Colfax et al., 2009; Dani et al., 2006; Horwitz et al., 2006). Having integrity and superior interpersonal skills relates to EI theories, because the individuals with higher EQs have the ability to gauge others' emotions and adjust their communication style and personal interaction accordingly (Brown \& Moshavi, 2005; Frye et al., 2006; Goleman, 1995). These results continue to support the theory of EI being a positive predeterminant and characteristic for virtual team members.

\section{Conclusion}

Due to varying reasons, an increasing number of organizations are utilizing virtual teams. Virtual teams work in dispersed, often self-managed climates and rely heavily on technology to communicate with team members and to manage and coordinate projects. Managing teams has never been an easy task for leaders, and even more problems arise when leaders must manage virtual teams. Virtual team members and leaders are required to take on unique tasks and typically experience high failure rates. This study sought to understand if Emotional Intelligence improved virtual team members' performance and contributed to project success.

The study involved analyzing virtual team members and included several participants who were in different locations throughout the United States. The researcher utilized surveys and the data were captured via electronic media communication. The findings showed significant results depicting that virtual team members felt that EI characteristics contributed to project success. The author utilized the Virtual Team Personality Matrix to depict specific characteristics that align with EI traits. The implications of this current research can provide organizational leaders with a blueprint depicting the type of employees they should seek while staffing virtual team projects. Organizations can also use these findings to develop personality screening test to decide whether candidates for virtual teams possess the EI characteristics necessary to succeed on virtual teams.

The study could be beneficial to any organization currently using virtual teams or teleworking programs or that are investigating the possible implementation of the groups. The study can be a blueprint to determine who should lead virtual teams, participate in the groups, and be excluded from virtual programs. The study could also identify the type of individuals that are more fitting for collocated teams than for virtual teams.

Understanding, improving, and implementing virtual teams can allow more employees to work remotely, reduce the need for office space and facilities expenses, and reduce the environmental footprint of many organizations. The study is relevant to a wide range of industries, fields, and specializations worldwide. Corporations of all sizes, entrepreneurs, public organizations, online universities or universities with distance learning 
programs, project management institutions, vendor managers, and research and development teams are just some of the groups that could benefit from the current research project. The financial implications and strategic advantages are extremely beneficial to organizations that are capable of accurately implementing and leading self-managed virtual teams. By utilizing an Emotional Intelligent framework and seeking employees that have characteristics related to the theory, organizations can significantly improve virtual team project performance.

\section{References:}

1. Amurgis, W. (2007). Paving the way for an intranet revolution at AEP. Strategic Communication Management, 11(3), 8-102. Retrieved from http://www.melcrum.com/products/journals/scm.shtml

2. Anantatmula, V., \& Thomas, M. (2010). Managing global projects: A structured approach for better performance. Project Management Journal, 41(2), 60-72. doi:10.1002/pmj.20168

3. Bacon, N., \& Blyton, P. (2006). The effects of co-operating or conflicting over work restructuring: Evidence from employees. Sociological Review, 54, 1-19. doi:10.1111/j.1467954X.2006.00599.x

4. Bielski, L. (2005). What makes a good leader? American Bankers Association, 97(12), 21-24. Retrieved from http://www.aba.com/

5. Bogdan, R. C., \& Bilken, S. K. (1992). Qualitative research for education: An introduction to theories and methods. Boston, MA: Allyn \& Bacon.

6. Brown, F. W., \& Moshavi, D. (2005). Transformational leadership and emotional intelligence: A potential pathway for an increased understanding of interpersonal influence. Journal of Organizational Behavior, 26, 867-871. doi:10.1002/job.334

7. Colfax, R. S., Santos, A. T., \& Diego, J. (2009). Virtual leadership: A green possibility in critical times but can it work? Journal of International Business Research, 8, 133-139. Retrieved from http://www.jibs.net/

8. Colquitt, J., \& Piccolo, R. (2006). Transformational leadership and job behaviors: The mediating role of core job characteristics. Academy of Management Journal, 49, 327-340. doi:10.5465/AMJ.2006.20786079

9. Copeland, M. (2006). The mighty micro-multinational. Business 2.0, 7(6), 106-114. Retrieved from http://money.cnn.com/magazines/business2/

10. Cottrell, C. A., Neuberg, S. L., \& Li, N. P. (2007). What do people desire in others? A Socio-functional perspective on the importance of 
different valued characteristics. Journal of Personality \& Social Psychology, 92, 208-231. doi:10.1037/0022-3514.92.2.208

11. Cramton, C. D. (2001). The mutual knowledge problem and its consequences for dispersed collaboration. Organization Science, 12, 346-371. doi:10.1287/orsc.12.3.346.10098

12. Creswell, J. W. (2009). Research design: Qualitative, quantitative, and mixed methods approaches. Thousand Oaks, CA: Sage.

13. Dani, S., Burns, N., Backhouse, C., \& Kochhar, A. (2006). The implications of organizational culture and trust in the working of virtual teams. International

14. Journal of Networking and Virtual Organizations, 220, 951-960. doi:10.1243/09544054JEM415

15. Ferbrache, C. P. (2009). Virtual team leader emergence: A model to objectively measure leader emergence (Master's thesis). Available from ProQuest Dissertations and Theses database. (UMI No. 1484525)

16. Frye, C. M., Bennett, R., \& Caldwell, S. (2006). Team emotional intelligence and team interpersonal process effectiveness. MidAmerican Journal of Business, 21, 49-56. doi:10.1108/19355181200600005

17. Furumo, K. (2009). The impact of conflicted and conflict management style on deadbeats and deserters in virtual teams. The Journal of Computer Information Systems, 49(4), 66-74. Retrieved from http://www.iacis.org/jcis/

18. Furst, S. A., Reeves, M., Rosen, B. S., \& Blackburn, R. S. (2004). Managing the life cycle of virtual teams. Academy of Management Executive, 18, 6-20. doi:10.5465/AME.2004.13837468

19. Ginsburg, J. P. (2009). Determining the personality characteristics that identify a successful global virtual team members (Doctoral dissertation). Retrieved from ProQuest Dissertation and Theses database. (UMI No. 3394314)

20. Goleman, D. (1995). Emotional intelligence: Why it can matter more than $I Q$.

a. New York, NY: Bantam Books.

21. Goleman, D. (2001). An EI based theory of performance. Retrieved from http://www.eiconsortium.org

22. Gratton, L., Voigt, A., \& Erickson, T. J. (2007). Bridging faultlines in diverse teams. MIT Sloan Management Review, 40(4), 22-29. Retrieved from http://sloanreview.mit.edu/

23. Horwitz, F. M., Bravington, D., \& Silvis, U. (2006). The promise of virtual teams: Identifying key factors in effectiveness and failure. Journal of European Industrial Training, 30, 472-494. doi:10.1108/03090590610688843 
24. Hutcheson, P. G. (2006). Creating a development culture through mentoring. Employment Relations Today, 33(2), 25-33. doi:10.1002/ert.20105

25. Kossler, M. E., \& Prestridge, S. (2003). Going the distance: The challenges of leading dispersed team. Leadership in Action, 23(5), 36. doi:10.1002/lia.1036

26. Krosigk, V. B. (2007). A holistic exploration of leadership development. South African Journal of Business Management, 38(2), 25-30. Retrieved from http://www.journals.co.za/ej/ejour_busman.html

27. Malhotra, A., Majchrzak, A., \& Benson, R. (2007). Leading virtual teams. Academy of Management Perspectives, 2, 60-70. doi:10.5465/AMP.2007.24286164

28. Mancini, D. J. (2010). Building organizational trust in virtual teams. Journal of Behavioral Studies in Business, 2, 1-5. Retrieved from http://www.aabri.com/jbsb.html

29. Moustakas, C. (1994). Phenomenological research methods. London, England: Sage.

30. Panteli, N., \& Tucker, R. (2009). Power and trust in global virtual teams. Communications of the ACM, 52(12), 113-115. doi:10.1145/1610252.1610282

31. Prati, L. M., Douglas, C., Ferris, G. R., Ammeter, A. P., \& Buckley, M. R. (2003). Emotional intelligence, leadership, effectiveness, and team outcomes. The International Journal of Organizational Analysis, 11, 21-40. doi:10.1108/eb028961

32. Quisenberry, W. (2011). Determining the common characteristics and attributes of self-managed virtual teams. (Doctoral dissertation). Available from ProQuest Dissertations and Theses database (UMI No. 3481272).

33. Qureshi, S., Liu, M., \& Vogel, D. (2006). The effects of electronic collaboration in distributed project management. Group Decision and Negotiation, 15, 55-75. doi:10.1007/s10726-005-9006-6

34. Rapisarda, B. A. (2002). The impact of emotional intelligence on work team cohesiveness and performance. The International Journal of Organizational Analysis, 10, 363-378. doi:10.1108/eb028958

35. Reed, A. H., \& Knight, L. V. (2010, Fall). Project risk differences between virtual and co-located teams, Journal of Computer Information Systems, 19-30. doi:10.1016/j.ijproman.2009.08.002

36. Rozell, E. J., \& Scroggins, W. A. (2010). How much is too much? The role of emotional 
37. intelligence in self-managed work team satisfaction and group processes. Team Performance Management, 16, 33-49. doi:10.1108/13527591011028915

38. Simon, M. (2006). Recipes for success: Dissertation \& scholarly research. Dubuque, IA: Kendall/Hunt.

39. Thomas, D. M., \& Bostrom, R. P. (2010). Vital signs for virtual teams: An empirically developed trigger model for technology adaption interventions. MIS Quarterly, 34, 115-142. Retrieved from http://www.misq.org/

40. Wagner, R., \& Harter, J. K. (2007, November 8). The seventh element of great managing. Gallup Management Journal Online, 1-7. Retrieved from http://gmj.gallup.com 